\title{
Involucrin in the differential diagnosis between linear psoriasis and inflammatory linear verrucous epidermal nevus: a report of one case
}

Involucrina na diagnose diferencial entre a psoríase linear e o nevo epidérmico verrucoso inflamatório linear: relato de um caso

Flávia Regina Ferreira ${ }^{1}$

Márcia Lanzoni de Alvarenga ${ }^{3}$
Nilton Gioia Di Chiacchio²

Samuel Henrique Mandelbaum ${ }^{4}$

\begin{abstract}
Inflammatory linear verrucous epidermal nevus is a variant of verrucous epidermal nevus, characterized by recurrent inflammatory phenomena. Despite well-established clinical manifestations, the differential diagnosis between inflammatory linear verrucous epidermal nevus and linear psoriasis remains difficult. Clinical history, physical examination and histopathology analysis may not be sufficient to confirm the diagnosis. We report the case of a 4-year-old girl in which the involucrin immunostaining was helpful in the diagnosis of inflammatory linear verrucous epidermal nevus. Our findings confirm that involucrin immunohistochemistry is a useful tool in such cases.
\end{abstract}

Keywords: Immunohistochemistry; Nevus; Psoriasis

Resumo: O nevo epidérmico verrucoso inflamatório linear é uma variante do nevo epidérmico verrucoso caracterizada por fenômenos inflamatórios recorrentes. A despeito das manifestações clínicas bem estabelecidas o diagnóstico diferencial entre nevo epidérmico verrucoso inflamatório linear e psoríase linear permanece difícil. A história clínica, o exame físico e análise histopatológica podem não ser suficientes para a confirmação diagnóstica. Nós relatamos o caso de uma menina de 4 anos de idade no qual o uso da involucrina foi útil para o diagnóstico do nevo epidérmico verrucoso inflamatório linear . Nossos achados corroboram a imunohistoquímica com a involucrina como uma ferramenta importante nestes casos.

Palavras-chave: Imunoistoquímica; Nevo; Psoríase

Received on 25.02.2012.

Approved by the Advisory Board and accepted for publication on 31.05 .2012

* Study conducted at the University Hospital of Taubaté - University of Taubaté (HUT-UNITAU) - Taubaté (SP), Brazil.

Conflict of interest: None

Financial funding: None

Master of Science, School of Medicine - Federal University of São Paulo (EPM-UNIFESP) - III Assistant Professor of Dermatology, Department of Medicine, University of Taubaté (UNITAU) - Taubaté (SP), Brazil.

Medical Doctor - Resident in the Department of Dermatology, University Hospital of Taubaté - Taubaté University (HUT-UNITAU) - Taubaté (SP), Brazil

Specialist in Pathology - Assistant Professor I of the Department of Medicine, University of Taubaté (UNITAU) - Taubaté (SP), Brazil.

Specialist in Dermatology - Assistant Professor of Dermatology, Department of Medicine, University of Taubaté (UNITAU). Head of Dermatology Department, University Hospital of Taubaté (HUT-UNITAU) - Taubaté (SP), Brazil. 


\section{INTRODUCTION}

Inflammatory Linear Verrucous Epidermal Nevus (ILVEN) is a variant of verrucous epidermal nevus characterized by recurrent inflammatory phenomena, providing a clinical aspect resembling chronic eczema or psoriasis. ${ }^{1}$

Differentiating between linear psoriasis, lichen striatum and other linear dermatoses is not always easy, and clinical history, physical examination and histopathology analysis may not be sufficient to confirm the diagnosis. The immunohistochemical staining (IHC) of anti-involucrin is a helpful alternative for differentiating these dermatoses when clinical and histopathology exams cannot easily do it. Involucrin is a marker of epidermal differentiation, a precursor protein of the cornified envelope, and staining is used as a tool to distinguish between psoriasis and ILVEN. ${ }^{2}$ It has been reported that a difference exists in the pattern of involucrin expression between the two diseases. ${ }^{3}$ We demonstrate how IHC with anti-involucrin can be used to differentiate these two entities.

\section{CASE REPORT}

A 4-year-old girl presented with numerous confluent verrucous papules, either hypochromic or erythematous, linearly distributed, some along the Blaschko's lines, on the trunk, upper and lower limbs, since birth (Figure 1). No other skin lesions, or ungueal, scalp or mucosal lesions were detected. Lesions were located initially in the back of the patient's right hand, with dissemination to the rest of trunk and limbs over the years. The lesions were pruritic. Her medical history suggested substantial reaction to food allergies. She had a twin sister without skin lesions and there was no family history of psori-

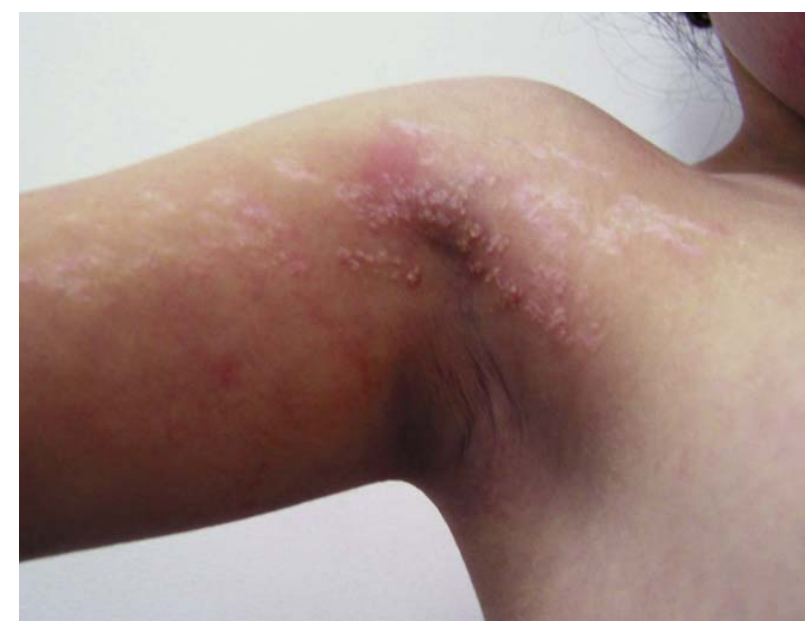

FIGURE 1: Numerous confluent verrucous papules, either hypocromic or erythematous, linearly distributed asis or of any other skin disorder. Given the clinical aspect, the diagnostic hypotheses were ILVEN, ichthyosis hystrix, linear psoriasis, incontinentia pigmenti and lichen striatus. Histopathologic examination revealed a psoriasiform dermatitis, consistent with the clinical hypothesis of ILVEN and linear psoriasis, and it was not possible to differentiate between the two (Figure 2). Results of immunohistochemical staining for involucrin revealed that this protein expression was increased in the orthokeratotic regions but deficient in the parakeratotic regions (Figure 3). The patient received topical treatment with keratolytics and steroids, as well as systemic treatment with antihistaminic drugs. The treatments resulted in moderated improvement of the lesions and pruritus.

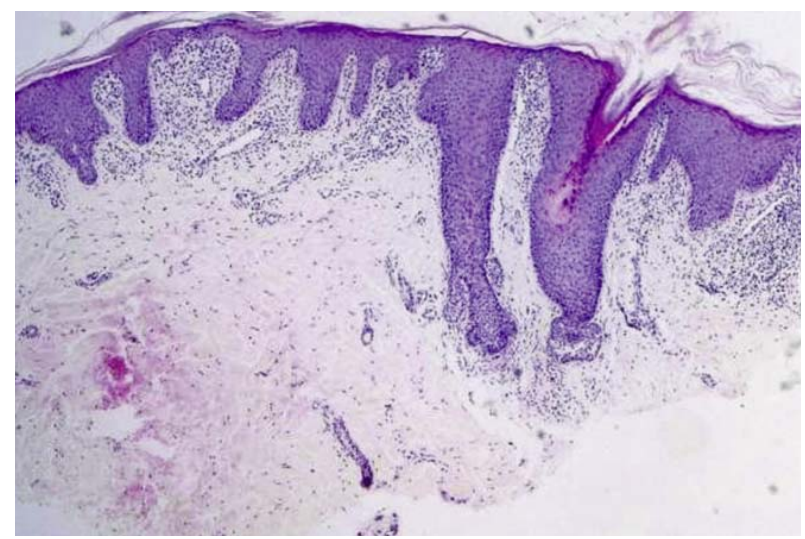

FIgURE 2: Psoriasiform dermatitis

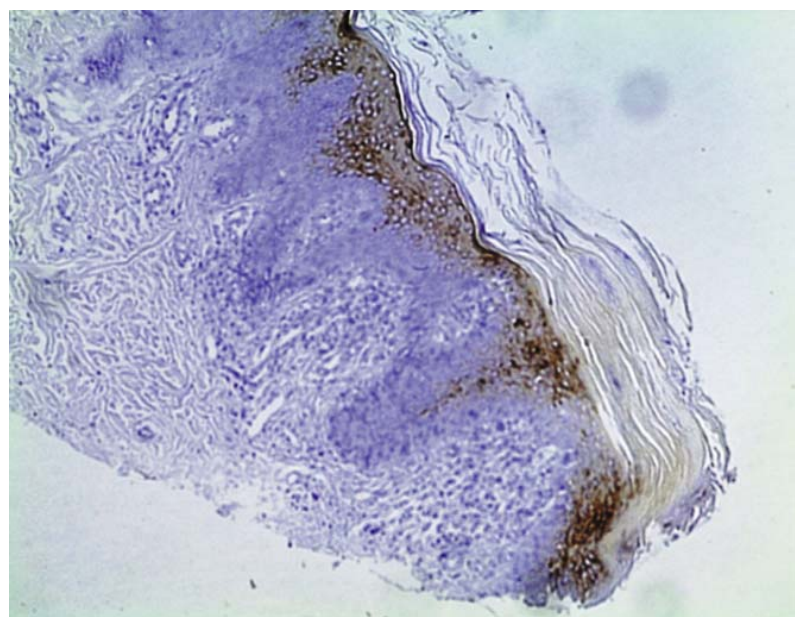

FIGURE 3: ILVEN: Staining for involucrin deficient in parakeratotic regions 


\section{DISCUSSION}

ILVEN is a rare skin disease characterized by unilateral lichenoid, verrucous or psoriasiform lesions. The lesions converge to form plaques and linear bands and may have a clinical resemblance to psoriasis. ${ }^{4-6}$ In 1971 Altman and Mehregan defined clinical criteria for the diagnosis of ILVEN: early onset (before 5 years of age in $75 \%$ of the cases); $4: 1$ predominance in females; frequent involvement of the left lower extremity; pruritus; psoriasiform appearance, following the lines of Blaschko; and persistent lesions showing marked resistance to treatment. ${ }^{5}$ Most cases are sporadic, although familial cases have been described. ${ }^{1}$ Diagnosis tends to be particularly difficult in cases that do not fulfill the classic criteria for ILVEN, or in those with both nevoid and psoriatic lesions. Various histopathologic features (acanthosis, papillomatosis, the presence of ortho- and parakeratotic areas, and changes of the papillary dermis) are typically observed in all difficult cases, and are clearly not useful for diagnosis. ${ }^{2,7-8}$ In such cases, authors have generally chosen one of three diagnoses: unilateral psoriasis, ILVEN, or Koebner's phenomenon on a pre-existing epidermal nevus in a subject with psoriatic diathesis. ${ }^{79,10-11}$ Even with meticulous history, detailed clinical examination, including examination of other family members, and close follow-up to observe the progression of the disease, differential diagnosis is sometimes difficult. ${ }^{2}$ An objective test to differentiate between unilateral psoriasis and ILVEN is the pattern of involucrin expression in the epidermis. Involucrin is a $68 \mathrm{kDa}$ precursor of the cornified envelope that was originally described by Rice and Green (1979) and ultimately cloned by Eckert and Green (1986). The protein is rod-shaped and includes several reactive glutamine residues that function in the formation of covalent isopeptide bonds. Involucrin is cross-linked early in cornified envelope formation and forms a scaffold for incorporation of other precursors. Involucrin expression initiates in the early spinous layer and is maintained in the granular layer. In the transition zone, involucrin is incorporated via the action of transglutaminase as a component of the cornified envelope..$^{12}$ In the normal epidermis it is present in the upper part of the squamous cell layer and in the granular layer, but in psoriasis it is detectable at deeper levels, from the suprabasal keratinocytes upwards (Figures 4 and 5). ${ }^{13-15}$ Ito and colleagues showed that in ILVEN the involucrin expression is increased in orthokeratotic regions but is deficient in parakeratotic regions; by contrast, in parakeratotic areas of psoriasis, most suprabasal keratinocytes express involucrin., ${ }^{3,7}$ Other authors have suggested that the behavior of other markers (elastin, antikeratin 10, antikeratin 16, Ki-67) may be useful to

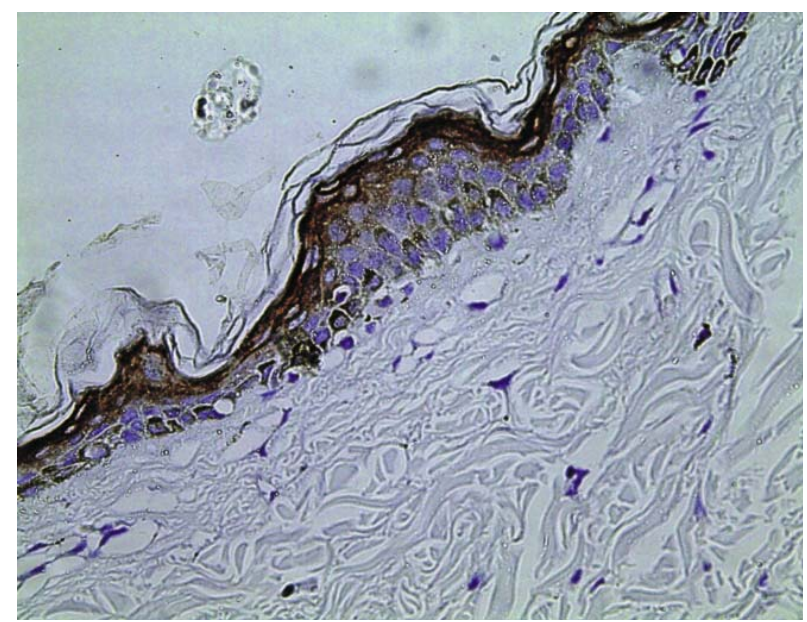

FIGURE 4: Normal skin: Involucrin in the upper part of the squamous cell layer and the granular layer

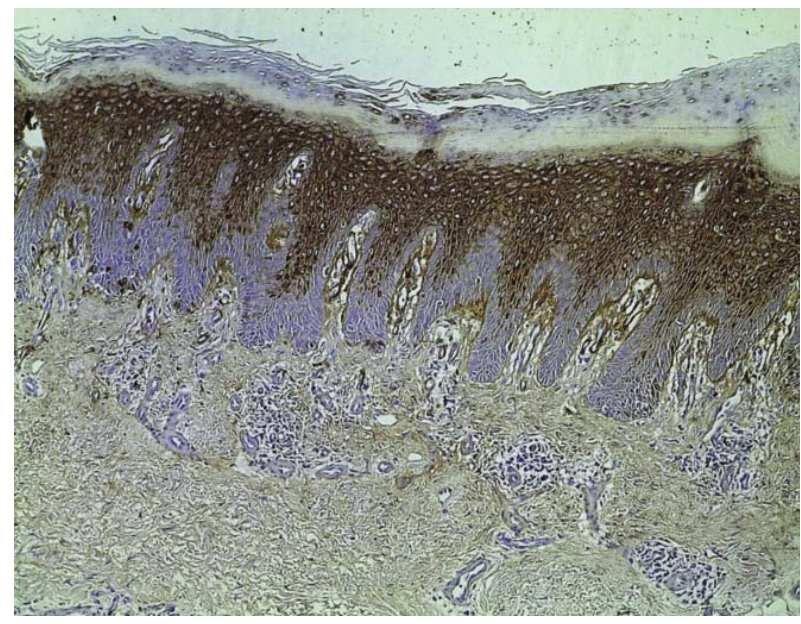

FIGURE 5: Psoriasis: Involucrin from the suprabasal keratinocytes upwards

differentiate between unilateral psoriasis and ILVEN. ${ }^{6,8}$ Differentiation between ILVEN and unilateral psoriasis is clearly important since the two disorders respond to treatment in different ways. Our case represents a situation where the clinical and histologic features were unable to make the definitive diagnosis between linear psoriasis and ILVEN, but the study of involucrin could give us a further clue, thereby helping to establish a more accurate diagnosis with a better chance of an effective therapeutic management of the disorder.

\section{ACKNOWLEDGMENT}

The authors wish to thank Fernanda Guedes Luiz, PhD, biologist at the Tropical Dermatology Laboratory, University of São Paulo, for performing the IHC stains. 


\section{REFERENCES}

1. Gon AS, Minelli L, Franzon PGU. Case for diagnosis. Bilateral inflammatory linear verrucous epidermal nevus (ILVEN). An Bras Dermatol. 2010;85:729-31.

2. Saraswat A, Sandhu K, Shukla R, Handa S. Unilateral Linear Psoriasis with Palmoplantar, Nail, and Scalp Involvement. Pediatr Dermatol. 2004;21:70-3.

3. Ito M, Shimizu N, Fujiwara H, Maruyama T, Tezuka M. Histopathogenesis of inflammatory linear verrucose epidermal naevus: histochemistry, immunohistochemistry and ultrastructure. Arch Dermatol Res. 1991;283:491-9.

4. Cheesbrough MJ, Kilby PE. The inflammatory linear verrucous epidermal naevusa case report. Clin Exp Dermatol. 1978;3:293-8.

5. Altman J, Mehregan AH. Inflammatory linear verrucose epidermal nevus. Arch Dermatol. 1971;104:385-9.

6. Vissers WH, Muys L, Erp PE, de Jong EM, van de Kerkhof PC Immunohistochemical differentiation between inflammatory linear verrucous epidermal nevus (ILVEN) and psoriasis. Eur J Dermatol. 2004;14:216-20.

7. Ginarte M, Fernández-Redondo V, Toribio J. Unilateral psoriasis: a case individualized by means of involucrin. Cutis. 2000;65:167-70.

8. De Jong EMGJ, Rulo HFC, Van De Kerkhof PCM. Inflammatory linear verrucous epidermal nevus (ILVEN) versus linear psoriasis. A clinical, histological and immunohistochemical study. Acta Derm Venereol (Stockh). 1991;71:343-6.

9. Bondi EE. Psoriasis overlying an epidermal nevus. Arch Dermatol. 1979;115:624-5.

10. Bennett RG, Burns L, Wood MG. Systematized epidermal nevus: a determinant for the localization of psoriasis. Arch Dermatol. 1973;108:705-7.

11. Toribio J, Quinones PA. Inflammatory linear verrucose epidermal nevus. Dermatologica. 1975;150:65-9.

12. Eckert RL, Crish JF, Efimova T, Dashti SR, Deucher A, Bone F, et al. Regulation of involucrin gene expression. J Invest Dermatol. 2004;123:13-22.

13. Bernard BA, Robinson SM, Vandaele S, Mansbridge JN, Darmon M. Abnormal maturation pathway of keratinocytes in psoriatic skin. $\mathrm{Br} \mathrm{J}$ Dermatol. 1985;112: 647-53.

14. Bernard BA, Reano A, Darmon YM, Thivolet J. Precocious appearance of involucrin and epidermal transglutaminase during differentiation of psoriatic skin. $\mathrm{Br} J$ Dermatol. 1986;114:279-83.

15. Dover $\mathrm{R}$, Watt FM. Measurement of the rate of epidermal terminal differentiation expression of involucrin by S-phase keratinocytes in culture and in psoriatic plaques. J Invest Dermatol. 1987;89:349-52.

\author{
MAILING ADDRESS: \\ Nilton Gioia Di Chiacchio \\ Avenida Granadeiro Guimarães, 270 - Centro \\ 12020-130 - Taubaté - SP \\ Brazil \\ E-mail: niltongioia@terra.com.br
}

How to cite this article: Ferreira FR, Di Chiacchio NG, de Alvarenga ML, Mandelbaum SH. Involucrin in the differential diagnosis between linear psoriasis and inflammatory linear verrucous epidermal nevus: report of one case. An Bras Dermatol. 2013;88(4):604-7. 